\title{
Properties of ternary NiFeW alloy coating by jet electrodeposition
}

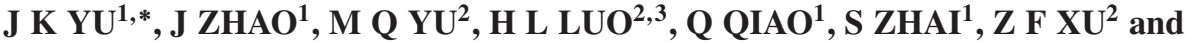 \\ KAZUHIRO MATSUGI ${ }^{2}$ \\ ${ }^{1}$ State Key Laboratory of Metastable Materials Science and Technology, Yanshan University, Qinhuangdao 066004, \\ People's Republic of China \\ ${ }^{2}$ Graduate School of Engineering, Hiroshima University, 1-4-1, Kagamiyama, Higashi-Hiroshima 739-8527, Japan \\ ${ }^{3}$ Hebei Provincial Key Laboratory of Heavy Machinery Fluid Power Transmission and Control, Yanshan University, \\ Qinhuangdao 066004, People's Republic of China \\ *Author for correspondence (yujinku@ysu.edu.cn)
}

MS received 18 May 2017; accepted 1 September 2017; published online 23 March 2018

\begin{abstract}
In this paper, ternary NiFeW alloy coatings were prepared by jet electrodeposition, and the effects of lord salt concentration, jet speed, current density and temperature on the properties of the coatings, including the composition, microhardness, surface morphology, structure and corrosion resistance, were investigated. Results reveal that the deposition rate reaches a maximum value of $27.30 \mu \mathrm{m} \mathrm{h}^{-1}$, and the total current efficiency is above $85 \%$. The maximum microhardness is $605 \mathrm{HV}$, and the wear and corrosion resistance values of the alloy coating are good. Moreover, the ternary NiFeW alloy coating is smooth and bright, and it presents a dense cellular growth. The alloy plating is nanocrystalline and has face-centered cubic structure.
\end{abstract}

Keywords. Jet electrodeposition; NiFeW alloy coating; current efficiency; microstructure; microhardness.

\section{Introduction}

Interest in the electrodeposition of $\mathrm{NiFeW}$ ternary alloys has increased rapidly in recent years because of their excellent properties, such as physical, chemical and mechanical properties. The introduction of tungsten into $\mathrm{NiFe}$ alloy coatings improves their microhardness [1-6], wear resistance [5-7], corrosion resistance [8-10] and uniformity organization [11-14]. There are many studies about the excellent properties of FeW and NiW alloy coatings [15-19]. Ternary $\mathrm{NiFeW}$ alloy coatings may exhibit the excellent properties of the FeW and NiW alloy coatings, while eliminating the unwanted properties of the binary alloy coatings [20-24]. However, systematic researches on the electrodeposition of the NiFeW alloy coatings are yet to be conducted $[4,23]$. Zhan et al [23] and Donten et al [4] have conducted several experiments on the effects of various concentrations of electrolyte and electroplating parameters on the compositions and appearances of the NiFeW alloy coatings. However, the properties and microstructure of these deposits were scarcely studied.

In the present study, NiFeW alloy coatings were prepared through jet electrodeposition from an environmentally friendly electrolyte. The composition of the NiFeW alloy coatings can be controlled by adjusting the process parameters

J K Yu conceived the project. J Zhao, M Q Yu, H L Luo and S Zhai designed the experiments. and electrolyte components. Their structure and properties such as microhardness, wear resistance and corrosion resistance were studied in detail and compared systematically. The optimized process conditions of electroplating $\mathrm{NiFeW}$ alloy were proposed.

\section{Experimental}

To ensure the surface quality of the copper plate substrate, we used a $13 \mathrm{~mm} \times 13 \mathrm{~mm}$ industrial pure copper plate as the substrate and performed the following pretreatments before plating. The substrate was first immersed in a mixed solution of $270 \mathrm{~g} \mathrm{l}^{-1}$ sulphuric acid and $40 \mathrm{~g}^{-1}$ hydrochloric acid mixed solution to remove the pure copper oxide on the surface. Then, the copper plate was immersed in a $5 \mathrm{~g} \mathrm{l}^{-1}$ of $\mathrm{NaOH}$, $5 \mathrm{~g} \mathrm{l}^{-1}$ of $\mathrm{Na}_{2} \mathrm{CO}_{3}, 10 \mathrm{gl}^{-1}$ of $\mathrm{Na}_{3} \mathrm{PO}_{4}$ and $1 \mathrm{ml} \mathrm{l}^{-1}$ of OP-10 mixed solution to remove cutting oils, washed in $60-70^{\circ} \mathrm{C}$ hot water and cold water, respectively, weakly etched in a $10 \%$ $\mathrm{Ni}\left(\mathrm{NH}_{2} \mathrm{SO}_{3}\right)_{2} \cdot 4 \mathrm{H}_{2} \mathrm{O}$ solution for $10 \mathrm{~min}$, and finally washed with deionized water.

The following chemicals were used: $\mathrm{Na}_{2} \mathrm{WO}_{4} \cdot 2 \mathrm{H}_{2} \mathrm{O}(40$ $\left.\mathrm{g} \mathrm{l}^{-1}\right), \mathrm{Ni}\left(\mathrm{NH}_{2} \mathrm{SO}_{3}\right)_{2} \cdot 4 \mathrm{H}_{2} \mathrm{O}\left(300 \mathrm{~g} \mathrm{l}^{-1}\right), \mathrm{FeCl}_{2} \cdot 4 \mathrm{H}_{2} \mathrm{O}$ (3 $\left.\mathrm{g} \mathrm{l}^{-1}\right), \mathrm{NiCl}_{2} \cdot 4 \mathrm{H}_{2} \mathrm{O}\left(5 \mathrm{~g} \mathrm{l}^{-1}\right), \mathrm{Na}_{3} \mathrm{C}_{6} \mathrm{H}_{5} \mathrm{O}_{7} \cdot 2 \mathrm{H}_{2} \mathrm{O}$ $\left(40 \mathrm{~g}^{-1}\right), \mathrm{H}_{3} \mathrm{BO}_{3}\left(40 \mathrm{~g} \mathrm{l}^{-1}\right)$, sodium dodecyl sulfate (as a wetting agent, $0.02 \mathrm{~g} \mathrm{l}^{-1}$ ), saccharin (as stress removal agent and brighteners, $\left.5 \mathrm{~g} \mathrm{l}^{-1}\right)$ and ascorbic acid $\left(V_{\mathrm{c}}\right.$ as stabilizer, $\left.3 \mathrm{gl}^{-1}\right)$. A current density $\left(D_{\mathrm{K}}\right)$ of $10-200 \mathrm{~A} \mathrm{dm}^{-2}$, a pH value 
of $3.8-4.2$, a temperature of $50-65^{\circ} \mathrm{C}$, jet speed of $0-5 \mathrm{~m} \mathrm{~s}^{-1}$ and a copper sheet (as the cathode material) were used for plating. Analytical reagents and deionized water were used for the plating bath, where $5 \mathrm{~g} \mathrm{l}^{-1}$ of $\mathrm{NaOH}$ or $10 \mathrm{~g} \mathrm{l}^{-1}$ of $\mathrm{Ni}\left(\mathrm{NH}_{2} \mathrm{SO}_{3}\right)_{2} \cdot 4 \mathrm{H}_{2} \mathrm{O}$ was used to control the $\mathrm{pH}$ value.

A HS-4800 field scanning electron microscope (FSEM) (Hitachi, East Coast Port City, Honshu Island) attached with an INC250 spectrometer (energy dispersive spectroscopy (EDS)) was used to analyse the morphology and $\mathrm{Ni}, \mathrm{Fe}$ and W contents of NiFeW alloy coatings. A FM-ARS9000 hardness tester was used to measure the hardness of the NiFeW alloy coatings. The applied force and time were $50 \mathrm{~g}$ and $15 \mathrm{~s}$, respectively. The hardness value was obtained from the average value of hardness from five measurements.

The deposition rate is characterized by the coating thickness difference method. The thickness of the samples before and after electrodeposition was measured by using a micrometer. Before every thickness measurement, the samples were cleaned with ethanol and dried completely. The coating deposition rate was obtained by dividing the thickness difference by the electrodeposition time. The deposition rate was obtained by computing the average value of the five measurements.

A CHI660A electrochemical workstation was used to measure the polarization curves to derive the corrosion resistance of the alloy coatings in a $3.5 \mathrm{wt} \% \mathrm{NaCl}$ solution. A threeelectrode cell, which comprises a NiFeW alloy coating as the working electrode, a platinum piece as the counter electrode and a saturated calomel electrode as the reference electrode, was used. The polarization curves were measured at an initial potential of $-1.3 \mathrm{~V}$, a final potential of $1.2 \mathrm{~V}$ and a scan rate of $10 \mathrm{mv} \mathrm{s}^{-1}$.

The computing method of the current efficiency shown below is based on the analysis of the components of the ternary alloy membrane [24].

$$
\eta=\frac{\sum_{i=1}^{n} G \times a_{i} \times k_{i}}{Q_{\text {total }}} \times 100 \%
$$

where $n$ is the number of components $(n=3), G$ is the total weight of coatings $(\mathrm{g}), a_{i}$ is $i$ th percentage of components in the alloy and $k_{i}$ is the $i$ th electrochemical equivalent value of the components $\left(\mathrm{Ah} \mathrm{g}^{-1}\right)$.

\section{Results and discussion}

In this work, $\mathrm{NiFeW}$ alloy coatings were prepared according to the optimal solution formula with different concentrations of $\mathrm{FeCl}_{2} \cdot 4 \mathrm{H}_{2} \mathrm{O}, \mathrm{Na}_{2} \mathrm{WO}_{4} \cdot 2 \mathrm{H}_{2} \mathrm{O}$ and $\mathrm{Ni}\left(\mathrm{NH}_{2} \mathrm{SO}_{3}\right)_{2} \cdot 4 \mathrm{H}_{2} \mathrm{O}$ in the plating bath. The process parameters were temperature $\left(60^{\circ} \mathrm{C}\right), D_{K}\left(60 \mathrm{~A} \mathrm{dm}^{-2}\right)$, jet speed $\left(3 \mathrm{~m} \mathrm{~s}^{-1}\right)$ and $\mathrm{pH}$ value (4.0). The influence of the lord salt concentration on the $\mathrm{NiFeW}$ alloy coating contents and microhardness was investigated.

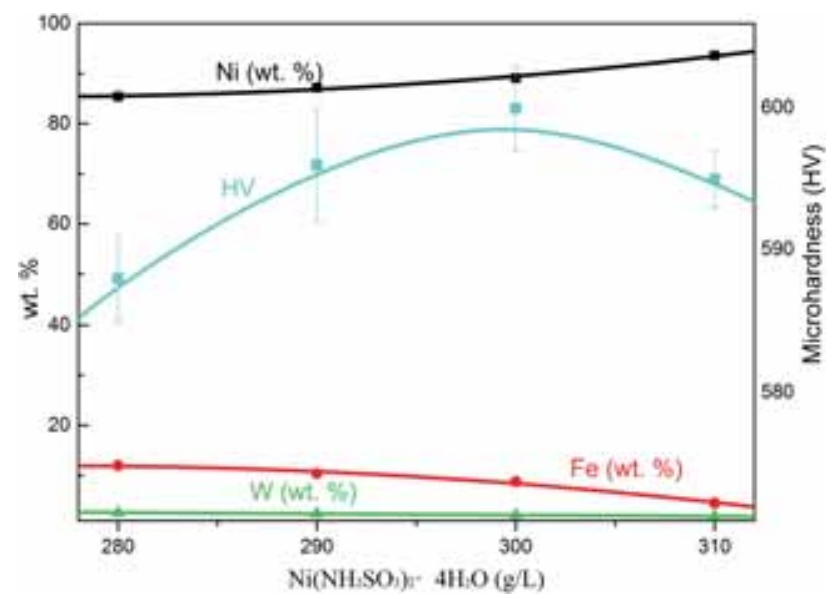

Figure 1. Composition and microhardness of the coating vs. $\mathrm{Ni}\left(\mathrm{NH}_{2} \mathrm{SO}_{3}\right)_{2}$ concentration of the plating bath. The $\mathrm{W}$ and $\mathrm{Fe}$ contents decrease with the increasing $\mathrm{Ni}\left(\mathrm{NH}_{2} \mathrm{SO}_{3}\right)_{2} \cdot 4 \mathrm{H}_{2} \mathrm{O}$ concentration in the plating bath. First, the microhardness increases and subsequently decreases with increasing $\mathrm{Ni}\left(\mathrm{NH}_{2} \mathrm{SO}_{3}\right)_{2} \cdot 4 \mathrm{H}_{2} \mathrm{O}$ concentration in the plating bath.

The relation curve of the $\mathrm{Ni}\left(\mathrm{NH}_{2} \mathrm{SO}_{3}\right)_{2} \cdot 4 \mathrm{H}_{2} \mathrm{O}$ concentration and the $\mathrm{Fe}$ and $\mathrm{W}$ content and the microhardness of $\mathrm{NiFeW}$ alloy coatings is shown in figure 1 . The $\mathrm{W}$ and $\mathrm{Fe}$ contents in $\mathrm{NiFeW}$ alloy coatings decrease with the increase in the $\mathrm{Ni}\left(\mathrm{NH}_{2} \mathrm{SO}_{3}\right)_{2} \cdot 4 \mathrm{H}_{2} \mathrm{O}$ concentration in the plating bath. The $\mathrm{W}$ content decreased from 2.60 to $1.90 \%$, and the Fe content tend to decrease very quickly from 12.10 to $4.52 \%$ with the increase in the $\mathrm{Ni}\left(\mathrm{NH}_{2} \mathrm{SO}_{3}\right)_{2} \cdot 4 \mathrm{H}_{2} \mathrm{O}$ concentration in the range of 280-310 $\mathrm{g}^{-1}$. In the electrodeposition process, $\mathrm{Ni}^{2+}$ concentration increases with increase in the $\mathrm{Ni}\left(\mathrm{NH}_{2} \mathrm{SO}_{3}\right)_{2}$. $4 \mathrm{H}_{2} \mathrm{O}$ concentration in the plating bath, and it will increase the concentration of $\mathrm{Ni}^{2+}$ near the cathode, the proportion increases of hydrate $\mathrm{Ni}^{2+}$ in the deposition reaction, it prevents the deposition of $\mathrm{Fe}^{2+}$ and $\mathrm{WO}_{4}^{2-}$. Thus, the Ni content in coatings increases and the $\mathrm{W}$ and Fe contents decrease.

The microhardness of the $\mathrm{NiFeW}$ alloy first increases, then decreases with the increase in the $\mathrm{Ni}\left(\mathrm{NH}_{2} \mathrm{SO}_{3}\right)_{2} \cdot 4 \mathrm{H}_{2} \mathrm{O}$ concentration in the plating bath. A Ni( $\left.\mathrm{NH}_{2} \mathrm{SO}_{3}\right)_{2} \cdot 4 \mathrm{H}_{2} \mathrm{O}$ concentration of $300 \mathrm{~g} \mathrm{l}^{-1}$ and alloy coating maximum microhardness of $602 \mathrm{HV}$. The alloy coatings obeyed the direct Hall-Petch relation above a critical size, where the hardness increased with decrease in crystallite size and the inverse Hall-Petch relation below a critical size [13]. To guarantee the quality of the alloy coating and maintain the alloy coating deposition rate, the $\mathrm{Ni}\left(\mathrm{NH}_{2} \mathrm{SO}_{3}\right)_{2} \cdot 4 \mathrm{H}_{2} \mathrm{O}$ concentration of $300 \mathrm{~g} \mathrm{l}^{-1}$ was chosen.

Figure 2 shows the curve of the $\mathrm{Na}_{2} \mathrm{WO}_{4}$ concentration in the plating bath, and the microhardness and the $\mathrm{W}$ and Fe contents of the NiFeW alloy coatings. The figure shows that the $\mathrm{Na}_{2} \mathrm{WO}_{4}$ concentration in the plating bath does not affect the coating components significantly. Under certain conditions, the $\mathrm{Fe}^{2+}$ and $\mathrm{Ni}^{2+}$ concentrations in the plating bath remain the same, and the $\mathrm{W}$ content of NiFeW alloy coatings first 


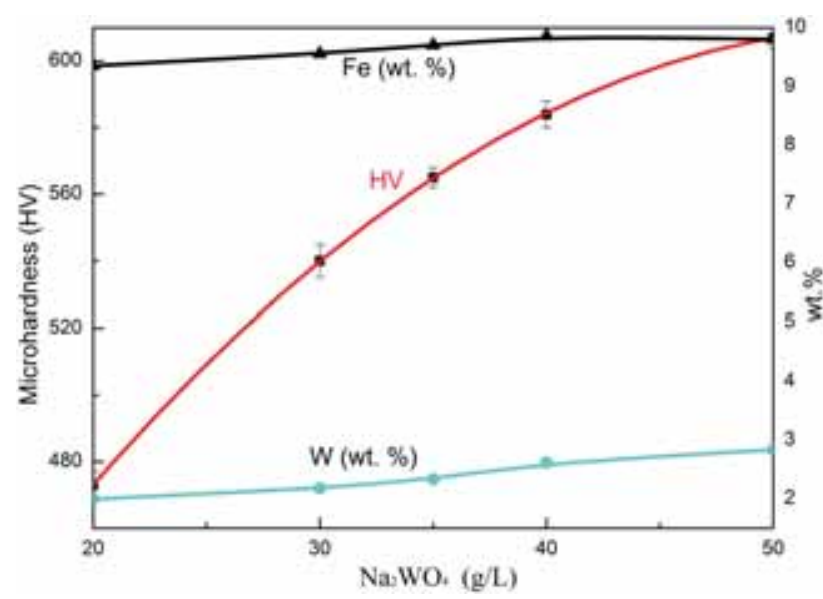

Figure 2. Microhardness and $\mathrm{W}$ and Fe contents of $\mathrm{NiFeW}$ alloy coatings $v s$. $\mathrm{Na}_{2} \mathrm{WO}_{4}$ concentration of the plating bath. The Fe and $\mathrm{W}$ contents increase with the increasing $\mathrm{Na}_{2} \mathrm{WO}_{4}$ concentration in the plating bath. The microhardness increases with increasing $\mathrm{Na}_{2} \mathrm{WO}_{4}$ concentration of the plating bath.

increases rapidly to a certain degree, then slows down with the increase in the $\mathrm{Na}_{2} \mathrm{WO}_{4}$ concentration. The changes in the Fe and $\mathrm{W}$ contents of NiFeW alloy coatings have the same trend. This shows that $\mathrm{W}$ and Fe deposits will interact. Under the process conditions, the $\mathrm{W}$ content of alloy coating reaches the maximum. After which, the $\mathrm{W}$ content of the alloy coating no longer increases as the $\mathrm{Na}_{2} \mathrm{WO}_{4}$ concentration of the plating bath increases. When the $\mathrm{Na}_{2} \mathrm{WO}_{4}$ concentration of the plating bath reaches more than $50 \mathrm{gl}^{-1}$, the $\mathrm{Na}_{2} \mathrm{WO}_{4}$ produces precipitation, and the $\mathrm{W}$ content of the alloy coatings increase slowly [23].

As shown in figure 2, the microhardness of the NiFeW alloy coatings was increased from 477 to $603 \mathrm{HV}$ with the increase in the $\mathrm{Na}_{2} \mathrm{WO}_{4}$ concentration of the plating bath form 20 to $50 \mathrm{~g}^{-1}$, and the coating hardness value increased to $125 \mathrm{HV}$. This is attributed to the increase in the $\mathrm{Na}_{2} \mathrm{WO}_{4}$ concentration of the plating bath that results in the increase in the $\mathrm{W}$ contents of alloy coatings from 2 to $3 \%$.

The relation curve of the $\mathrm{FeCl}_{2}$ concentration in the plating bath and the microhardness and the $\mathrm{W}$ and Fe contents in the $\mathrm{NiFeW}$ alloy coatings is shown in figure 3 . The $\mathrm{W}$ and $\mathrm{Fe}$ contents of the alloy coatings increase with the increase in the $\mathrm{FeCl}_{2}$ concentration in the plating bath. The $\mathrm{Fe}$ content increased from 3.30 to $6.98 \%$, and $\mathrm{W}$ content increased from 1.31 to $2.18 \%$ with the increase in the $\mathrm{FeCl}_{2}$ concentration from 1.50 to $3.00 \mathrm{~g} \mathrm{l}^{-1}$. In the process of electrodeposition, the ionic strength of $\mathrm{Fe}^{2+}$ increases with the increase in the $\mathrm{FeCl}_{2}$ concentration in the plating bath, and the $\mathrm{Fe}^{2+}$ concentration in cathode increases with the increase in the $\mathrm{Fe}^{2+}$ concentration in the plating bath, and this increase could promote the deposition of $\mathrm{Fe}^{2+}$. Thus, the $\mathrm{Fe}$ content in coatings increases. The $\mathrm{Fe}^{2+}$ of the plating bath and the $\mathrm{WO}_{4}^{2-}$ induced co-deposition effect leads to the increase in the $\mathrm{W}$ content of

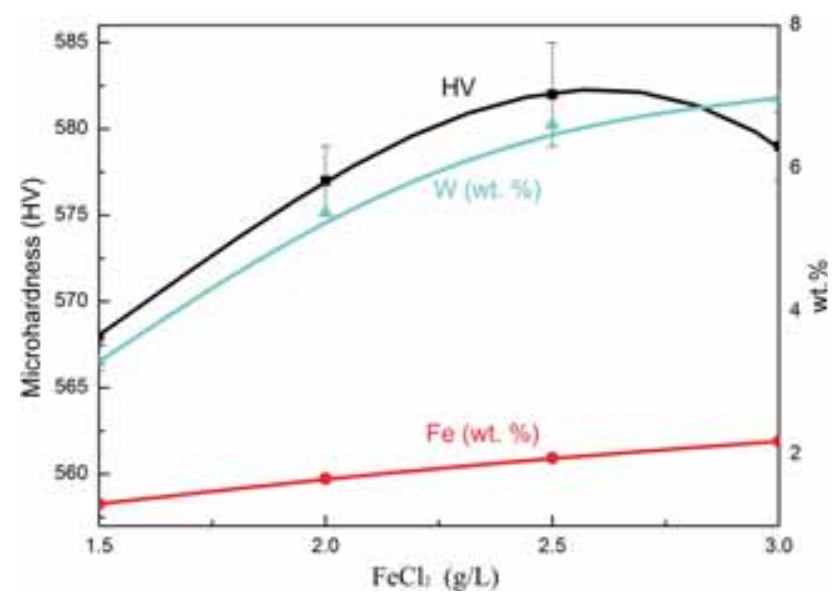

Figure 3. Microhardness and $\mathrm{W}$ and $\mathrm{Fe}$ contents of $\mathrm{NiFeW}$ alloy coatings vs. $\mathrm{FeCl}_{2}$ concentration of the plating bath. The $\mathrm{Fe}$ and W contents increase with the increasing $\mathrm{FeCl}_{2}$ concentration in the plating bath. First, the microhardness increases and subsequently decreases with the increasing $\mathrm{FeCl}_{2} \cdot 4 \mathrm{H}_{2} \mathrm{O}$ concentration in the plating bath.

the alloy coatings and the increase in the $\mathrm{FeCl}_{2}$ concentration of the plating bath.

The microhardness of the NiFeW alloy first increases, then decreases with the increase in the $\mathrm{FeCl}_{2}$ concentration of the plating bath. When the $\mathrm{FeCl}_{2}$ concentration was $2.0 \mathrm{~g} \mathrm{l}^{-1}$, the maximum microhardness for $\mathrm{NiFeW}$ alloy coatings was $580 \mathrm{HV}$. The Fe content of the alloy coatings increases because the $\mathrm{FeCl}_{2}$ concentration of the plating bath increases. Concurrently, the $\mathrm{W}$ content of the alloy coatings increases. Therefore, the microhardness of the alloy coatings increases.

The influence of jet speed $(v)$ on the content, microhardness, surface topography and microstructure of $\mathrm{NiFeW}$ alloy coatings was studied under a bath temperature of $60^{\circ} \mathrm{C}$ and a $D_{\mathrm{K}}$ of $60 \mathrm{~A} \mathrm{dm}^{-2}$. The relation curve of $v$ and the microhardness, and the $\mathrm{W}$ and $\mathrm{Fe}$ contents of the NiFeW alloy coatings are shown in figure 4. The $\mathrm{W}$ and Fe contents increase with the increase in $v$. The Fe content increased from 2.3 to $2.72 \%$ and the $\mathrm{W}$ content increased from 8.54 to $9.83 \%$ with the increase in $v$ in the range of $0-5 \mathrm{~m} \mathrm{~s}^{-1}$. Jet electrodeposition with a special power plant increases the moving velocity of metal ions; metal ions near the cathode are consumed, and the concentration polarization is reduced due to the slow ion migration.

In addition, as $v$ increases, the thickness of the cathode surface and the diffusion layers decreases, and the metal ion concentration of the surface and the diffusion layers increase. During electrodeposition, $\mathrm{Fe}^{2+}$ is reduced more easily than $\mathrm{Ni}^{2+}$, and $\mathrm{Fe}^{2+}$ is also preferably deposited. Thus, the $\mathrm{Fe}$ content of the $\mathrm{NiFeW}$ alloy coatings increases, and $\mathrm{Fe}^{2+}$ and $\mathrm{WO}_{4}^{2-}$ induce co-deposition. Consequently, the $\mathrm{Fe}$ and $\mathrm{W}$ contents of the alloy coatings increase with the increase in $v$.

The microhardness increases with the increase in $v$. When $v$ was $3 \mathrm{~m} \mathrm{~s}^{-1}$, the maximum microhardness of the alloy 


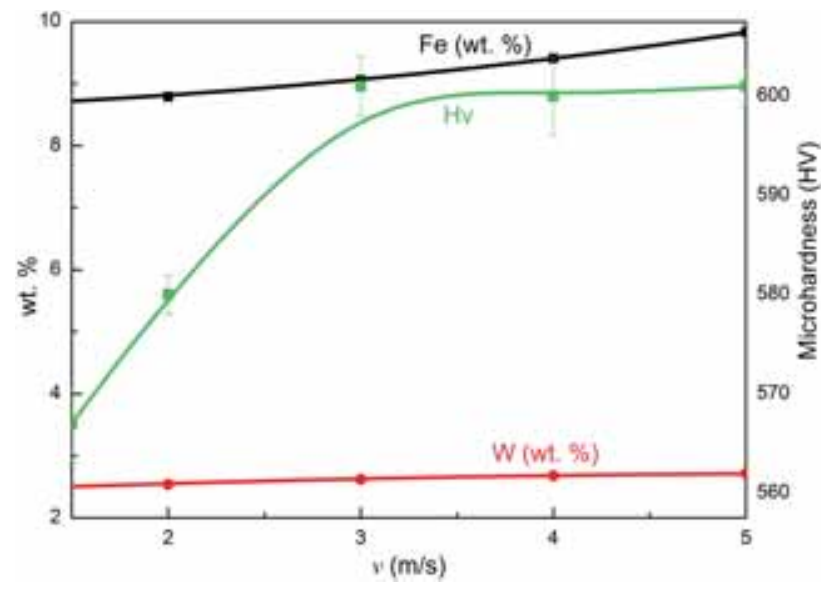

Figure 4. Microhardness and $\mathrm{W}$ and $\mathrm{Fe}$ contents of $\mathrm{NiFeW}$ alloy coatings $v s$. speed $(v)$. Fe and $\mathrm{W}$ contents increase with the increasing $v$. The microhardness of $\mathrm{NiFeW}$ alloy coatings increases with increasing $v$ value, reaches the maximum, and remains unchanged thereafter.

coating was $600 \mathrm{HV}$. This result can be explained by the decrease of the alloy coating grain size with the increasing $v$. Thereafter, the microhardness of the alloy coatings remains unchanged with the increasing $v$. Because of increase in the jet rate of the electrolyte, the concentration of ions increases in the deposition, the electrodeposition rate is accelerated, the grain size of alloy coating is reduced, and the hardness value of alloy coating increases. The alloy coatings obeyed the direct Hall-Petch relation. When jet rate of the electrolyte increases to a certain value, then the reaction speed no longer increases.

Figure 5 shows SEM images of the NiFeW alloy coatings at different $v$ values. The $\mathrm{NiFeW}$ ternary alloy plating surface presents a granular structure by common electroplating preparation (figure 5a). With the increase in $v$ of $1 \mathrm{~m} \mathrm{~s}^{-1}$, the alloy coating shows granular and cellular structures (figure $5 \mathrm{~b}$ ). When $v$ is $3 \mathrm{~m} \mathrm{~s}^{-1}$, the alloy coating surface displays a fully formed cellular structure (figure 5c). Moreover, the cellular structure of the NiFeW ternary alloy coating surface is observed, when $v$ continues to increase by $5 \mathrm{~m} \mathrm{~s}^{-1}$ (figure 5d). During crystal nucleus nucleation, low nucleation energy results in the high possibility of crystal nucleus formation, i.e., a high formation rate results in a fine crystalline grain size. In jet electrodeposition, the cathodic overpotential increases with the increase in $v$, thus, the nucleation rate increases, and the grain size is small [25]. There are two fundamental factors affecting grain size. They are rate of nucleation and crystal growth rate, when nucleation rate is greater than the growth rate of the nucleation, grain is refined. High cathode overpotential, high adsorption atomic number and low adsorption of atomic surface mobility were for a large number of nucleation, and inhibit the growth of grain. For jet electrodeposition, the cathode overpotential increases with jet velocity of the electrolyte increased, therefore, the
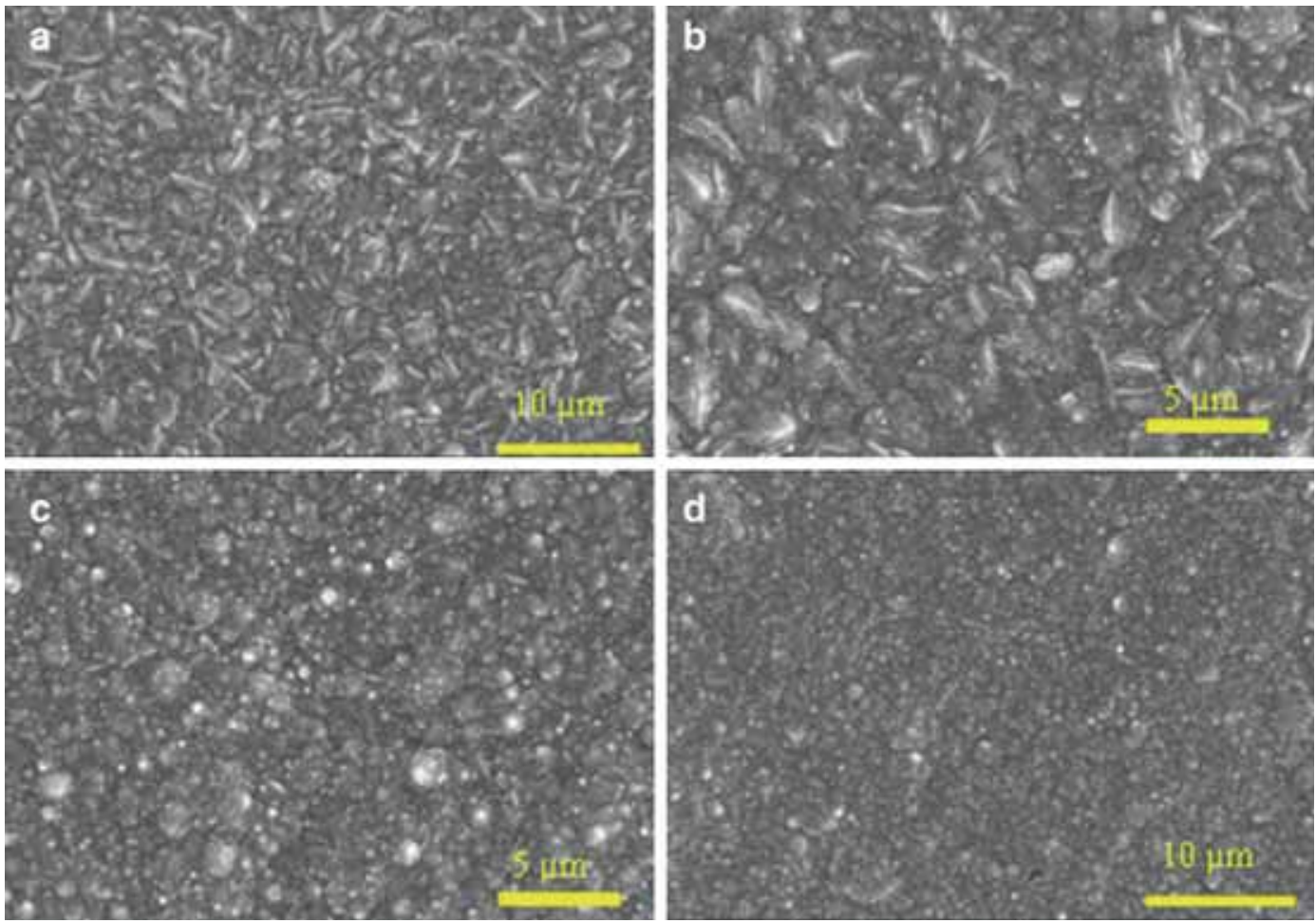

Figure 5. SEM images of the NiFeW alloy coatings in different $v$ values: (a) 0, (b) 30, (c) 60 and (d) $120 \mathrm{~m} \mathrm{~s}^{-1}$. The alloy coating surface topography changes from granular into cellular structure with increasing $v$ values. 


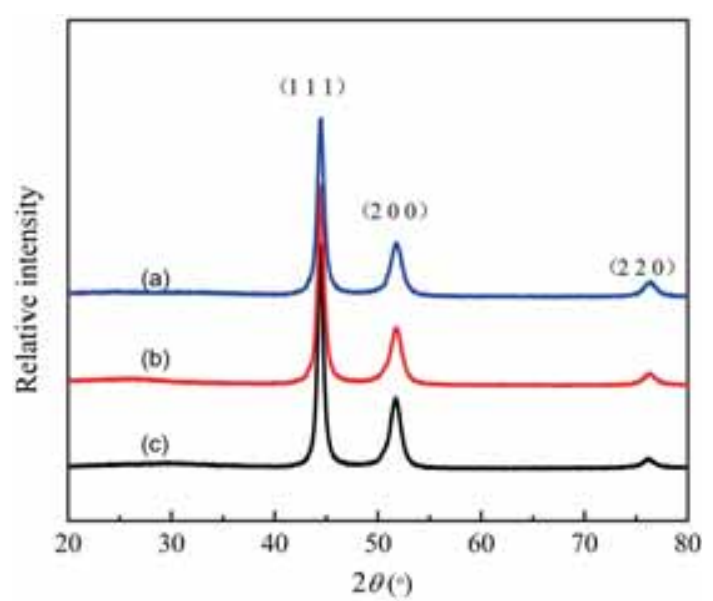

Figure 6. X-ray diffractometer patterns of the $\mathrm{NiFeW}$ alloy coatings with different $v$ values: (a) 0 , (b) 1.5 and (c) $3 \mathrm{~m} \mathrm{~s}^{-1}$.

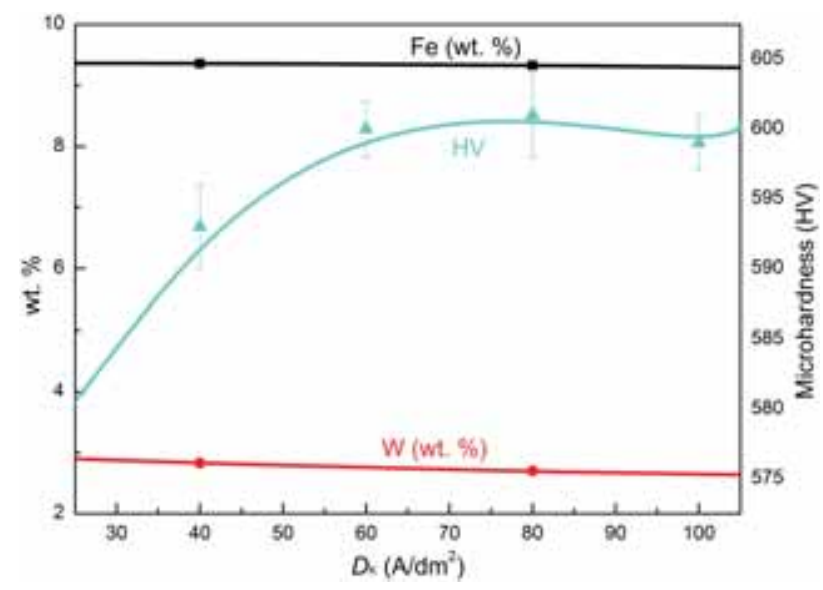

Figure 7. Microhardness and $\mathrm{W}$ and $\mathrm{Fe}$ contents of $\mathrm{NiFeW}$ alloy coatings vs. $D_{\mathrm{K}}$. The Fe and $\mathrm{W}$ contents are essentially unchanged with the increasing $D_{\mathrm{K}}$. The microhardness increases with increasing $D_{\mathrm{K}}$, reaches the maximum, and remains unchanged thereafter.

nucleation probability increases. And greater speed, thinner diffuse layer, precipitates and adsorption of more hydrogen ions on the cathode surface were preventing the $\mathrm{NiFeW}$ nucleus to grew up. Spray this form to make additional energy to enter the liquid to provide nuclear power, promoting nucleation, and crystal dendrite can be broken to increase the number of nuclei, thus, causing the grain size to decrease.

The relation curve of jet speed $(v)$ and microstructure of $\mathrm{NiFeW}$ alloy coatings is shown in figure 6, which indicates that the NiFeW ternary alloy coating is face-centered cubic structure. The (111) crystal orientation increases slightly with the increase in $v$. The alloy is made up of Ni-based solid solution and $\mathrm{Ni}_{3} \mathrm{Fe}$. The atomic radius of $\mathrm{Ni}$ is smaller than that of $\mathrm{Fe}$. To form the alloy coating, Ni atoms in the lattice original iron atoms will occupy the position and form Ni-based substitution solid solution; the radius difference between $\mathrm{Ni}$ and $\mathrm{Fe}$ changes the lattice constant and lattice distortion and hinders dislocation motion, thereby the grain refinement occurs [26].

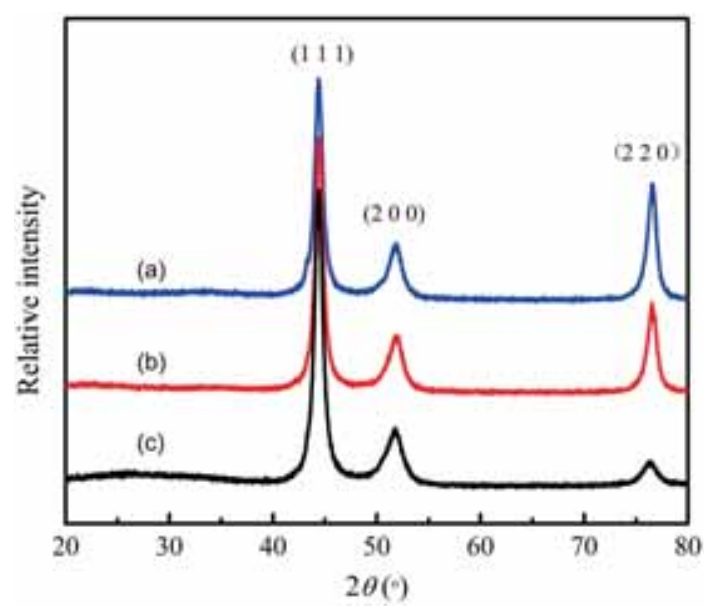

Figure 8. X-ray diffractometer patterns of the $\mathrm{NiFeW}$ alloy coatings with different $D_{\mathrm{K}}$ : (a) 10 , (b) 40 and (c) $60 \mathrm{~A} \mathrm{dm}^{-2}$. With the increase in $D_{\mathrm{K}}, \mathrm{NiFeW}$ alloy coating crystal orientation presents an apparent change from the initial (220) crystal orientation to (111).

Figure 7 shows the dependence of $D_{\mathrm{K}}$ on the microhardness and the $\mathrm{W}$ and $\mathrm{Fe}$ contents of the NiFeW alloy coatings. The $\mathrm{W}$ and $\mathrm{Fe}$ contents are essentially unchanged with increasing $D_{\mathrm{K}}$. Evidently, $D_{\mathrm{K}}$ exerts no influence on the $\mathrm{W}$ and Fe contents of the alloy coatings; in NiFeW-induced co-deposition, determining the influence of alloy composition on electrolytic parameters is difficult [27].

The microhardness of the NiFeW alloy coatings increases with the $D_{\mathrm{K}}$. When the $D_{\mathrm{K}}$ is $60 \mathrm{~A} \mathrm{dm}^{-2}$, the maximum microhardness of the alloy coating is $605 \mathrm{HV}$. Thereafter, the microhardness of alloy coatings remains unchanged.

The influence of $D_{\mathrm{K}}$ on the microstructure of the $\mathrm{NiFeW}$ alloy coatings was studied under a bath temperature of $60^{\circ} \mathrm{C}$ and $v$ of $3 \mathrm{~m} \mathrm{~s}^{-1}$. The results in figure 8 indicate that with increasing $D_{\mathrm{K}}$, the $\mathrm{NiFeW}$ alloy coating crystal orientation presents an apparent change from the initial (220) crystal orientation to (111). Furthermore, the NiFeW ternary alloy coatings do not produce a new phase with the change in orientation.

The tribological tests of the alloy coating were evaluated using a MMU-5G end-face friction and wear testing machine (Jinan, China), which employed a load of 1-10 kN (force value relative error, $\pm 1 \%$ ), a rotational speed of 5-2000 $\mathrm{r}$ $\min ^{-1}$ (error range, $\pm 10 \mathrm{r} \mathrm{min}^{-1}$ ), and a friction of $10-500 \mathrm{~N}$ (relative error of friction value, $\pm 2 \%$ ). The wear loss was calculated through the difference of the sample mass before and after the tribological tests. Each tribological test was repeated five times under the same conditions to reduce the artificial errors and obtain the standard deviations. The $\phi 40 \mathrm{~mm}$ coating samples with a polished surface were prepared through a wire cutting machine. The grinding material was $45 \#$ steel.

The experimental results are shown in table 1. The highest microhardness of the jet electrodeposition of the NiFeW ternary alloy plating is $605 \mathrm{HV}$. The erosion rate is lowest at $0.5734 \mathrm{~g}$. Introducing $\mathrm{W}$ elements improves the microhardness and wear resistance of the alloy coating. 
Table 1. Wear loss ( $\mathrm{g}$ ) of alloy coatings in the rotational speed of $100 \mathrm{r} \mathrm{min}^{-1}$, load of $100 \mathrm{~N}$ and time of $20 \mathrm{~min}$.

\begin{tabular}{lcc}
\hline Alloy coatings & Microhardness (HV) & Wear loss (g) \\
\hline NiFe & 476 & 1.2210 \\
NiFeW (ED) & 562 & 0.7452 \\
NiFeW (JD) & 605 & 0.5734 \\
\hline
\end{tabular}

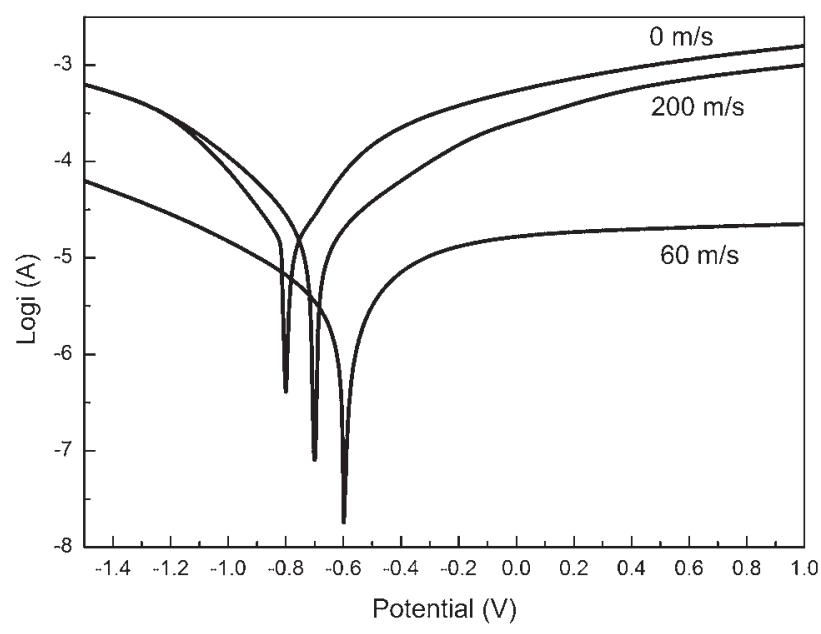

Figure 9. Cathodic polarization curves of the $\mathrm{NiFeW}$ alloy coatings with JED and ED.

Under the same experimental conditions, the friction and wear properties of alloy coatings and their hardness values are proportional. The increase in microhardness is helpful for the improvement of the alloy coating friction and wear performance [28].

Figure 9 shows the polarization curves of the NiFeW alloy coatings deposited using two different methods. The corrosion potential is -0.60 at the JED speed of $60 \mathrm{~m} \mathrm{~s}^{-1}$, which is more positive than that using ED. With the JED and a voltage above $-0.20 \mathrm{~V}$, the current is almost constant with the increasing voltage. This result suggests that the coating surface is passivated, i.e., a passivated layer is formed on the surface of the coating. This passivated layer can prevent the further corrosion of the coating. Passivation also occurs at $\sim-0.2 \mathrm{~V}$ using the following set of parameters: $60^{\circ} \mathrm{C}, \mathrm{pH}$ $=3,4 \mathrm{~A} \mathrm{dm}^{-2}, V_{\mathrm{c}}=3 \mathrm{~g} \mathrm{l}^{-1}$ and $v=60 \mathrm{~m} \mathrm{~s}^{-1}$. Evidently, the coating deposited using JED exhibits the highest corrosion resistance, which is mainly attributed to the smooth and dense surface, the smallest grain size, the least impurities, and the fact that the $\mathrm{Cl}^{-}$ions in the plating solution cannot easily penetrate coatings.

\section{Conclusions}

1. Preparation of the optimized formulation of the ternary alloy $\mathrm{NiFeW}: \mathrm{Ni}\left(\mathrm{NH}_{2} \mathrm{SO}_{3}\right)_{2} \cdot 4 \mathrm{H}_{2} \mathrm{O}, 300 \mathrm{~g} \mathrm{l}^{-1}$;
$\mathrm{Na}_{2} \mathrm{WO}_{4} \cdot 2 \mathrm{H}_{2} \mathrm{O}, 40 \mathrm{~g} \mathrm{l}^{-1} ; \mathrm{FeCl}_{2} \cdot 4 \mathrm{H}_{2} \mathrm{O}, 3.0 \mathrm{~g} \mathrm{l}^{-1}$; $\mathrm{NiCl}_{2} \cdot 4 \mathrm{H}_{2} \mathrm{O}, 5 \mathrm{~g} \mathrm{l}^{-1} ; \mathrm{Na}_{3} \mathrm{C}_{6} \mathrm{H}_{5} \mathrm{O}_{7} \cdot 2 \mathrm{H}_{2} \mathrm{O}, 40 \mathrm{~g} \mathrm{l}^{-1}$; $\mathrm{H}_{3} \mathrm{BO}_{3}, 40 \mathrm{~g} \mathrm{l}^{-1}$; sodium dodecyl sulphate, $0.1 \mathrm{~g} \mathrm{l}^{-1}$; saccharin, $5 \mathrm{~g} \mathrm{l}^{-1}$; and ascorbic acid $\left(V_{\mathrm{c}}\right), 3 \mathrm{~g} \mathrm{l}^{-1}$.

2. Plating parameters: $\mathrm{pH}$ value of $4.0, D_{\mathrm{K}}$ of $60 \mathrm{~A} \mathrm{dm}^{-2}$, temperature at $60^{\circ} \mathrm{C}$, and jet speed of $4 \mathrm{~m} \mathrm{~s}^{-1}$. Under the optimized formulation and technological conditions, the surface coating is uniform, bright and compact without obvious defects, and the coating possesses the crystalline NiFeW phase, which improves the performance of the copper substrate.

3. Under optimized formulation and technological conditions, the deposition rate is $27.3 \mu \mathrm{m} \mathrm{min}{ }^{-1}$ and the current efficiency is above $85 \%$.

4. Under optimized formulation and technological conditions, the maximum microhardness is $605 \mathrm{HV}$, and the wear and corrosion resistance values of the alloy coating are good.

\section{Acknowledgements}

We acknowledge the financial support from the Higher School of Science and Technology of Hebei Province in China (grant no. ZD2014055). This research work was also supported by the China Scholarship Council.

\section{References}

[1] Sriraman K R, Raman S G S and Seshadri S K 2007 Mater. Sci. Eng. A 460-461 39

[2] Zelenovic L R, Cirovic N, Spasojevic M, Mitrovic N, Maricic A and Pavlovic V 2012 Mater. Chem. Phys. 135212

[3] Oliveira A L M, Costa J D, Sousa M B D, Alves J J N, Campos A R N, Santana R A C et al 2015 J. Alloys Compd. 619697

[4] Donten M, Cesiulis H and Stojek Z 2000 Electrochim. Acta 45 3389

[5] Islam S H 2011 Rare Met. 30392

[6] He F J, Yang J, Lei T X and Gu C Y 2007 Appl. Surf. Sci. 253 7591

[7] Chang L M, Wang Z T, Shi S Y and W Liu 2011 J. Alloys Compd. 5091501

[8] Wang S, Zeng C, Ling Y H, Wang J J and Xu G Y 2016 Surf. Coat. Technol. 28636

[9] Ji X L, Yan C Y, Duan H and Luo C Y 2016 Surf. Coat. Technol. 302208

[10] Kumar U P, Kennady C J and Zhou Q Y 2015 Surf. Coat. Technol. 283148

[11] Moussa S O, Ibrahim M A M and Rehim S S A E 2006 J. Appl. Electrochem. 36333

[12] Zhong Z M and Clouser S J 2014 Surf. Coat. Technol. 240380

[13] Sriraman K R, Raman S G S and Seshadri S K 2006 Mater. Sci. Technol. 2214

[14] He J, He F L, Li D W, Liu Y L and Yin D C 2016 Colloids Surf. B 142325 
[15] Nagayama T, Yamamoto T and Nakamura T 2016 Electrochim. Acta 205178

[16] Matsui I, Mori H, Kawakatsu T, Takigawa Y, Uesugi T and Higashi K 2014 Mater. Sci. Eng. A 607505

[17] Yari S and Dehghanian C 2013 Ceram. Int. 397759

[18] Elias L and Hegde A C 2015 Surf. Coat. Technol. 28361

[19] Zemanová M, Krivosudská M, Chovancová M and Jorík V 2011 J. Appl. Electrochem. 411077

[20] Kiran U R, Kumar J, Kumar V, Sankaranarayana M, Nageswara Rao G V S and Nandy T K 2016 Mater. Sci. Eng. A 656 256

[21] Hou K H and Chen Y C 2011 Appl. Surf. Sci. 2576340
[22] Spasojević M, Zelenović L R, Maričić A and Spasojević P 2014 Powder Technol. 254439

[23] Zhan H Q, He F J, Ju H and Zhao R S 2008 J. Mater. Prot. 41 31

[24] Liu Y H and Yuan J M 1998 J. Mater. Prot. 3119

[25] Gu Z C and He L F 2010 Plat. Finish. 321

[26] Meng Q P, Rong Y H and Xu Z Y 2002 Sci. Chin. (Series E) 32457

[27] Li H, He Y, He T, Qing D Y, Luo F J, Fan Y et al 2017 J. Alloys Compd. $\mathbf{7 0 4} 32$

[28] Dong N, Zhang C L, Li J and Han P D 2016 Rare Met. Mater. Eng. 450885 